\title{
Modifikasi Media Jagung (Zea mays) dan Kacang Tanah (Arachis hypogea) sebagai Media Pertumbuhan Aspergillus flavus
}

\author{
NOVI FITRIA ${ }^{1}$, FUJI SETIAWATI ${ }^{1}$ \\ 1. Sekolah Tinggi Analis Bakti Bandung, Jl. Padasuka Atas 233 Bandung, 40192 \\ novi.fitria@staba.ac.id
}

\begin{abstract}
ABSTRAK
Komposisi media Sabouraud Dextrose Agar (SDA) terdiri dari dekstrosa, pepton dan agar sebagai pemadat media. Dekstrosa mengandung karbohidrat dan pepton mengandung protein sebagai unsur penting dalam pertumbuhan Aspergillus flavus. Jagung (Zea mays) dan kacang tanah (Arachis hypogea) dipilih sebagai media alternatif dikarenakan memiliki komposisi karbohidrat dan protein yang diperlukan oleh Aspergillus flavus. Secara eksperimen akan dilakukan variasi komposisi media alternatif berbahan dasar Zea mays dan Arachis hypogea dengan empat variasi media. Aspergillus flavus ditanam dengan teknik single dot dan diinkubasi selama 5 hari pada suhu $37^{\circ} \mathrm{C}$. Hasil penelitian menunjukkan bahwa media alternatif $B(15,75 \mathrm{~g}$ Zea mays dan 5,34g Arachis hypogea) memberikan diameter koloni dan panjang hifa yang tidak berbeda signifikan terhadap media SDA dengan nilai $p$ value secara berturut-turut adalah 0,188 dan 0,790. Pemanfaatan bahan alami dalam pembuatan media dapat menjadi alternatif teknologi green value chain di bidang mikrobiologi lingkungan.
\end{abstract}

Kata kunci: media alternatif, diameter koloni, panjang hifa, Aspergillus flavus.

\begin{abstract}
Sabouraud Dextrose Agar SDA media composition consists of dextrose, peptone and agar as a media compactor. Dextrose contains carbohydrate and peptone contains protein as an important element in the growth of Aspergillus flavus. Corn (Zea mays) and peanuts (Arachis hypogea) were chosen as alternative media because they have the composition of carbohydrates and proteins needed by Aspergillus flavus. Experiments will be carried out variations in the composition of alternative media made from corn and peanuts with four media variations. Aspergillus flavus is planted by single dot technique and incubated for 5 days at 37oC. The results showed that alternative media $B(15,75 \mathrm{~g}$ of corn and $5.34 \mathrm{~g}$ of peanut) gave a colony diameter and hyphae length that were not significantly different from the SDA media with $p$ values of respectively 0.188 and 0.790.
\end{abstract}

Keywords: alternative media, colony diameter, hyphae length, Aspergillus flavus. 


\section{PENDAHULUAN}

Kontaminasi aflatoksin dari Aspergillus flavus pada berbagai jenis pangan seperti jagung, gandum dan Arachis hypogea mengakibatkan kerusakan meliputi fisik, kimia, bau, warna, tekstur dan nilai nutrisi serta berakibat pada kesehatan manusia dan hewan (Supardi dan Sukamto, 1999; Abrunhosa, 2001). Toksin ini menyerang sistem imun tubuh manusia dan mekanisme kerja hati manusia, mamalia, maupun unggas sehingga menjadi faktor penyebab kanker hati (Adisarwanto, 2000; Cottyb \& Jaime-Garcia, 2007). Aspergillus sp sering mengkotaminasi berbagai jenis tanaman komersil seperti jagung dan kacang-kacangan (Probst dkk, 2014). Data tentang kontaminasi jamur Aspergillus sp maupun aflatoksin pada produk jagung diketahui berasal dari jenis Aspergillus flavus seperti kasus kontaminasi hasil panen jagung di Zambia dan Uganda (Paul dkk, 2017; Julius dkk, 2020). Hal ini menunjukkan bahwa jagung dan kacang-kacangan adalah media yang dapat ditumbuhi jamur Aspergillus flavus.

Media Sabouraud Dextrose Agar (SDA) merupakan media agar yang biasanya digunakan untuk pertumbuhan jamur. Sabouroud pada tahun 1910 sebagai media selektif untuk jamur dan ragi, pH asam $(5,6)$ dari media ini menghambat banyak spesies bakteri, media informasi dapat dibuat lebih selektif dengan penambahan kloramfenikol. Aspergillus flavus tumbuh optimum pada kelembaban $82-85 \%$, suhu $35-38^{\circ} \mathrm{C}$ dan $\mathrm{pH}$ asam (Reverberi dkk, 2005). Komposisi SDA terdiri dari pepton, agar, dextrosa yang berfungsi sebagai sumber energi untuk pertumbuhan jamur, pepton adalah hasil pemecahan protein yang dapat larut dalam air, berfungsi sebagai sumber nutrisi dan berperan dalam menjaga tekanan osmotik media (Guinea dkk, 2005).

Di laboratorium kebutuhan media SDA untuk menganalisis jamur Aspergillus flavus terkadang mengalami kendala dalam ketersediaannya. Oleh karena itu penelitian ini dilakukan untuk mengembangkan media alternatif pengganti media SDA yang berasal dari jagung (Zea mays) dan Arachis hypogea (Arachis hypogea).Sebagai upaya pemanfaatan bahan alami dan mengurangi pemakaian bahan sintetis kimia sehingga menjadi produk media yang ramah lingkungan dalam prosesnya.

\section{METODOLOGI}

\subsection{Material}

Aspergillus flavus tumbuh dengan memproduksi benang filamen bercabang seperti yang dikenal sebagai hifa yang dikenal sebagai miselium mengeluarkan enzim yang memecah sumber makanan yang kompleks, kemudian molekul-molekul yang dihasilkan diserap oleh miselium untuk bahan bakar pertumbuhan jamur tambahan (Ruban dkk, 2019). Hifa Aspergillus flavus mempunyai ciri-ciri bercabang, mempunyai septa dan selnya memiliki banyak inti dengan struktur yang khas adalah konidiofor (kepala konidium) dengan ujung berbentuk bulat yang disebut vesikel (Lan dkk, 2018). Koloni Aspergillus flavus pada saat muda berwarna putih dan akan berubah menjadi warna hijau kekuningan setelah membentuk konidia. Kepala konidia berwarna hijau kekuningan hingga hijau tua kekuningan, berbentuk bulat, konidiofor berdinding kasar, hialin, sedangkan vesikula berbentuk bulat hingga semi bulat (Samson dkk, 1999). Aspergillus falvus yang digunakan pada penelitian ini adalah Aspergillus flavus yang berasal dari hasil isolasi. 
Jagung dan Arachis hypogea di Indonesia merupakan komoditas penting sebagai bahan pangan, industri pakan ternak, bahan industri dan bahan dasar makanan olahan, jika pada lingkungan tanaman jagung terdapat Aspergillus flavus dan mencemari bakal jagung, maka jamur tersebut dapat bertahan sampai terbentuk tongkol jagung dan ditemukan pada saat pemanenan (Paul dkk, 2017; Julius dkk, 2020).

Perbandingan komposisi media SDA, Zea mays dan Arachis hypogea terdapat pada Tabel 1 berikut :

Tabel 1. Perbandingan Komposisi Bahan

\begin{tabular}{ccc}
\hline Media SDA & Zea Mays $/ 100 \mathrm{~g}$ & Arachis hypogea/ $100 \mathrm{~g}$ \\
\hline Dextrose $40 \mathrm{~g}$ & Karbohidrat 30,47\% & Karbohidrat 20,66\% \\
\hline Pepton $10 \mathrm{~g}$ & Protein 4,31\% & Protein 22,46\% \\
\hline \multicolumn{2}{c}{ Sumber : Balai Laboratorium Kesehatan Bandung, 2015 }
\end{tabular}

Jamur Aspergillus flavus tumbuh pada media agar dan biasanya dibuat dalam media formula yang harganya relatif mahal, selain itu juga, jika media tersebut tidak tersedia alangkah lebih baiknya menggunakan media alternatif lain selain media formula tersebut yang memiliki komposisi hampir sama dengan media formula, bahannya lebih alami, praktis, mudah didapat dan harganya lebih terjangkau, seperti Arachis hypogea yang berfungsi untuk menggantikan pepton sedangkan Zea mays sebagai pengganti dekstrosa yang terkandung dalam media SDA, kemudian ditambah agar-agar sebagai pemadat pada media alternatif.

\subsection{Metode}

Jenis penelitian yang dilakukan adalah bersifat eksperimen bertujuan untuk mengetahui suatu gejala atau pengaruh yang timbul, sebagai akibat dari adanya perlakuan terhadap media modifikasi dan diamati pengaruhnya terhadap media tersebut. Desain penelitian yang digunakan adalah Static Group Comparison yaitu suatu rancangan penelitian yang menggunakan dua kelompok subyek diantaranya kelompok perlakuan dan kelompok kontrol. Pada media modifikasi Arachis hypogea dan Zea mays sebagai kelompok eksperimen dan pertumbuhan jamur Aspergillus flavus pada media SDA sebagai kelompok kontrol. Pada media modifikasi Zea mays, kandungan karbohidratnya digunakan sebagai pengganti dextrose (media SDA) sebagai kontrol. Sedangkan media Arachis hypogea kandungan protein yang terdapat didalamnya, digunakan untuk menggantikan pepton (media SDA) sebagai kontrol. Desain penelitian tersedia pada Tabel 2.

Tabel 2. Desain Penelitian

\begin{tabular}{|c|c|c|}
\hline Kelompok & Perlakuan & Post test \\
\hline Eksperimen & $\begin{array}{l}\text { Media modifikasi (dengan } 4 \\
\text { variasi komposisi jagung dan } \\
\text { Arachis hypogea) media } \\
\text { modifikasi A, media modifikasi B, } \\
\text { media modifikasi C dan media } \\
\text { modifikasi D ditanami } 1 \text { ose koloni } \\
\text { jamur Aspergillus flavus secara } \\
\text { single dot }\end{array}$ & $\begin{array}{l}\text { Diukur diameter koloni dan } \\
\text { panjang hifa serta dilakukan uji } \\
\text { penegasan secara mikrosopis } \\
\text { yang kemudian dibandingkan } \\
\text { dengan kelompok kontrol }\end{array}$ \\
\hline Kontrol & $\begin{array}{l}\text { Media SDA (media kontrol) } \\
\text { ditanami } 1 \text { ose koloni jamur } \\
\text { Aspergillus flavus secara single } \\
\text { dot pada media SDA }\end{array}$ & $\begin{array}{l}\text { Diukur diameter koloni dan } \\
\text { panjang hifa serta uji penegasan } \\
\text { secara mikrosopis yang kemudian } \\
\text { dibandingkan dengan kelompok } \\
\text { eksperimen }\end{array}$ \\
\hline
\end{tabular}


Untuk menentukan jumlah pengulangan yang harus dilakukan dalam penelitian ini, maka dapat digunakan rumus Federer (1977) yaitu : $(n-1)(t-1) \geq 15$, dimana t adalah treatment (perlakuan), dalam hal ini ada 5 perlakuan (kelompok kontrol (SDA), perlakuan media modifikasi Zea mays dan Arachis hypogea (modifikasi A, modifikasi B, modifikasi C, modifikasi $\mathrm{D}$ ) dan $\mathrm{n}$ adalah replikasi atau pengulangan. Hasil perhitungan replikasi adalah $\geq$ 5 sehingga penelitian ini melakukan pengulangan sebanyak 5 kali pada setiap media modifikasi dan media kontrol. Keterangan media modifikasi terdapat pada Tabel 3.

Tabel 3. Komposisi Media Modifikasi

\begin{tabular}{cccc}
\hline Media Modifikasi A & Media modifikasi B & Media modifikasi C & Media modifikasi D \\
\hline Zea mays 7,87g & Zea mays 15,75g & Zea mays 31,50g & Zea mays 47,25g \\
\hline Arachis hypogea 5,34g & Arachis hypogea 5,34g & Arachis hypogea 5,34g & Arachis hypogea 5,34g \\
\hline
\end{tabular}

Alat-alat yang digunakan adalah mikroskop, autoklaf, inkubator, cawan petri, lampu spirtus, jarum ose, batang pengaduk, neraca, kasa asbes, gelas kimia, kaki tiga, Erlenmeyer, objeck glass, cover glass, corong tangkai pendek, kertas saring, kertas timbang, saringan. Sedangkan bahan-bahan yang digunakan adalah ekstrak pati Arachis hypogea dan Zea mays, Koloni Aspergillus flavus dari biakan murni dari Laboratorium Sekolah Tinggi Analis Bakti Asih Bandung, Media SDA (Sabouraud Dextrosa Agar), agar-agar serbuk, Aquadest, Alkohol 70\%, $\mathrm{NaCl}$ fisiologis dan LPCB (Lactophenol Cotton Blue), kloramfenikol, buffer pH 4.

Prosedur kerja yang dilakukan terdiri dari : (1) uji pendahuluan dan uji penegasan (2) sterilisasi alat : dilakukan dengan menggunakan autoklaf pada suhu $121^{\circ} \mathrm{C}$ selama 15 menit pada tekanan $1 \mathrm{~atm}$; (3) pembuatan media SDA (media kontrol) : ditimbang 7,8 g SDA dilarutkan dalam aquades $100 \mathrm{~mL}$ kemudian dipanaskan hingga mendidih, ditambahkan buffer hingga $\mathrm{pH} 4$ lalu disterilkan, setelah disterilkan ditambahkan antibiotik kloramfenikol sebanyak 0,85g dan dihomogenkan, agar SDA tuang daam cawan petri; (4) penetapan kadar protein pada Arachis hypogea (Arachis hypogea) dengan metode Kieldhal; (5) penetapan kadar gula jagung (Zea mays) dengan metode Luff Schrool; (6) pembuatan media modifikasi A, B, C dan D; (7) penanaman jamur; (8) pewarnaan jamur dengan metode LPCB; (9) mengukur diameter koloni; (10) mengukur panjang hifa dan (11) pengolahan data dengan menggunakan ANOVA dan Korelasi Pearson.

Disimulasikan perhitungan untuk menentukan berat Arachis hypogea yang digunakan agar setara dengan komposisi pepton $10 \mathrm{~g}$ dalam media SDA. Berdasarkan uji protein diketahui total protein dalam $100 \mathrm{~g}$ adalah 22,46 g maka untuk mendapatkan $10 \mathrm{~g}$ pepton dalam 120 $\mathrm{mL}$ adalah dengan menggunakan rumus sebagai berikut :

$$
\begin{gathered}
\frac{22,46 g}{100 g}=\frac{10 g}{x} \\
x=\frac{100 \times 10}{22,46}=44,52 g
\end{gathered}
$$

Jika akan dibuat media dengan volume $120 \mathrm{~mL}$ maka dilakukan perhitungan sebagai berikut

$$
\frac{44,52 g}{1000 m L}=\frac{x}{120 m L}
$$




$$
x=\frac{44,52 g \cdot 120 m L}{1000 m L}=5,34 g
$$

Disimulasikan perhitungan untuk menentukan berat Zea mays yang digunakan agar setara dengan komposisi dextrose $40 \mathrm{~g}$ dalam media SDA. Berdasarkan uji protein diketahui total protein dalam $100 \mathrm{~g}$ adalah 30,47 g maka untuk mendapatkan $40 \mathrm{~g}$ pepton dalam $120 \mathrm{~mL}$ adalah dengan menggunakan rumus sebagai berikut :

$$
\begin{gathered}
\frac{30,47 g}{100 g}=\frac{40 g}{x} \\
x=\frac{100 \times 40}{22,46}=131,3 g
\end{gathered}
$$

Jika akan dibuat media dengan volume $120 \mathrm{~mL}$ maka dilakukan perhitungan sebagai berikut :

$$
\begin{gathered}
\frac{131,3 \mathrm{~g}}{1000 \mathrm{~mL}}=\frac{x}{120 \mathrm{~mL}} \\
x=\frac{131,3 \mathrm{~g} \cdot 120 \mathrm{~mL}}{1000 \mathrm{~mL}}=15,75 \mathrm{~g}
\end{gathered}
$$

Untuk mendapatkan $40 \mathrm{~g}$ dextrosa maka jumlah Zea mays yang ditimbang adalah $15,75 \mathrm{~g}$. Disiapkan Arachis hypogea dan Zea mays yang sudah ditimbang dengan menggunakan timbangan neraca analitik sebanyak 5,34 gram untuk Arachis hypogea dan Zea mays sebanyak 7,87 g untuk modifikasi A ( setengah dari komposisi dekstrosa SDA), modifikasi B $15,75 \mathrm{~g}$ (setara dengan komposisi pepton SDA), modifikasi C sebanyak $31,5 \mathrm{~g}$ (2x dari komposisi dekstrosa SDA) dan modifikasi D sebanyak 47.25g (3x dari komposisi dekstrosa SDA).

\section{ISI (HASIL DAN PEMBAHASAN)}

Uji penegasan dan uji pendahuluan dilakukan pada media modifikasi A dengan variasi kloramfenikol 0,5g, 0,75g dan 0,85g. Hasil uji pendahuluan menunjukkan bahwa Aspergillus flavus mampu tumbuh di media modifikasi $A$ dengan bebas kontaminasi pada penggunaan kloramfenikol $0,85 \mathrm{~g}$. Hasil uji penegasan menunjukkan bahwa objek yang diamati adalah betul jamur jenis Aspergillus flavus, dan data tersedia pada Gambar 1. 


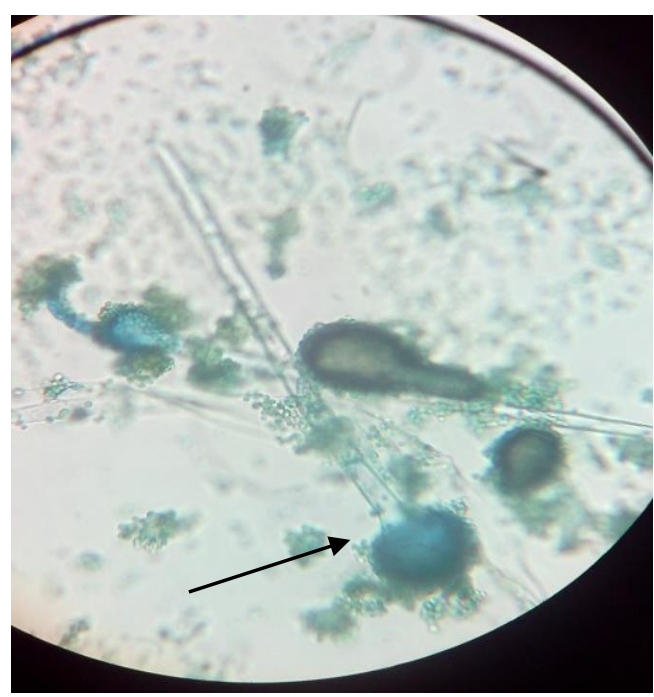

\section{Gambar 1. Uji Penegasan Aspergillus flavus pada media SDA secara mikroskopis dengan} perbesaran $10 \times 40$

Hasil pengamatan diameter koloni dan panjang hifa Aspergillus flavus selama 5 hari pada setiap kelompok eksperimen dan kelompok kontrol tersedia pada Tabel 4

Tabel 4. Diameter koloni (cm) dan panjang hifa( $\mu \mathrm{m})$

\begin{tabular}{cccc}
\hline Media & N & $\begin{array}{c}\text { Rata-rata diameter } \\
\text { koloni }(\mathrm{cm})\end{array}$ & $\begin{array}{c}\text { Rata-rata panjang } \\
\text { hifa }(\mu \mathrm{m})\end{array}$ \\
\hline SDA & 5 & $4,30 \pm 0,65$ & $179,6 \pm 48,2$ \\
\hline Modifikasi A & 5 & $2,96 \pm 0,52$ & $187,6 \pm 40,59$ \\
\hline Modifikasi B & 5 & $3,42 \pm 0,50$ & $209,4 \pm 39,66$ \\
\hline Modifikasi C & 5 & $2,87 \pm 0,89$ & $213,6 \pm 29,97$ \\
\hline Modifikasi D & 5 & $3,36 \pm 0,33$ & $237,0 \pm 47,55$ \\
\hline
\end{tabular}

Pengolahan data menggunakan SPSS Versi 25 untuk menganalisis apakah terdapat perbedaan diameter koloni dan panjang hifa yang signifikan antara media modifikasi dengan media kontrol. Analisis data menggunakan ANOVA satu arah. Sebelum dilakukan uji ANOVA data di uji homogenitas dan memberikan hasil yang homogen dengan $p$ value 0,119 untuk diameter koloni dan $p$ value 0,655 untuk panjang hifa. Hasil uji ANOVA menunjukkan nilai $p$ value 0,011 < 0,05 untuk diameter koloni dan $p$ value 0,245 $>0,05$ untuk panjang hifa. Hal tersebut membuktikan bawa berdasarkan diameter koloni terdapat perbedaan yang signifikan sedangkan pada parameter panjang hifa tidak terdapat perbedaan yang signifikan. Dikarenakan hasil uji ANOVA diameter koloni $\mathrm{p}$ value $<0,05$ maka dilakukan uji Post Hoc yang tersedia di Tabel 5 .

\section{Tabel 5. Diameter koloni (cm) dan panjang hifa( $\mu \mathrm{m})$}

\begin{tabular}{cccc}
\hline Media & N & $\begin{array}{c}\text { Subset for alpha } \\
=0,05(1)\end{array}$ & $\begin{array}{c}\text { Subset for alpha } \\
=0,05(2)\end{array}$ \\
\hline Modifikasi C & 5 & $2,87 \pm 0,89$ & \\
\hline Modifikasi A & 5 & $2,96 \pm 0,52$ & \\
\hline Modifikasi D & 5 & $3,36 \pm 0,33$ & $3,36 \pm 0,33$ \\
\hline Modifikasi B & 5 & & $3,42 \pm 0,50$ \\
\hline SDA & 5 & & $4,30 \pm 0,65$ \\
\hline
\end{tabular}


Berdasarkan uji post hoc maka diketahui bahwa media modifikasi B dan D berada pada satu subset yaitu subset 2, maka media B dan D memberikan diameter koloni yang tidak berbeda signfikan sedangan media $C$ dan A memberikan perbedaan yang signifikan. Namun dari kedekatan rata-rata maka media modifikasi $\mathrm{B}$ memberikan hasil yang paling mendekati dengan media SDA dengan $\mathrm{p}$ value 0,188 .

Dari penelitian yang dilakukan maka diperoleh keterangan bahwa pertumbuhan jamur memerlukan suatu medium yang mengandung nutrien yang meliputi air, karbon dan faktor tumbuh (Ernawati \& Adipati, 2017). Selain itu, jamur memerlukan karbohidrat sebagai sumber energi, protein sebagai penyusun tubuh dan mineral sebagai zat yang dapat menunjang pertumbuhan spora (Lan dkk, 2018). Jamur tumbuh pada lingkungan yang lembab dan suhu tropik, khususnya Aspergillus flavus (Julius dkk, 2020).

Media yang digunakan pada penelitian ini adalah SDA yang berfungsi sebagai media kontrol. Pada media ini secara makroskopis jamur Aspergillus flavus koloni nya tumbuh pada hari ke2 setelah penanaman, adapun sifat morfologis Aspergillus flavus secara mikroskopis yaitu bersepta, miselia bercabang biasanya tidak berwarna, konidiofor yang panjang (400 - 800 $\mu \mathrm{m}$ ) relatif kasar, bentuk kepala konidial bervariasi dari bentuk kolom, radial dan bentuk bola, hifa berseptum, koloni jamur ini memiliki warna permulaan kuning yang akan berubah menjadi kuning kehijauan atau coklat dengan warna inversi coklat keemasan atau tidak berwarna, sedangkan koloni yang sudah tua memiliki warna hijau tua, konidia berbentuk rantai berwarna kuning sampai hijau dan mungkin membentuk skerotia (Omeiza dkk, 2018).

Bahan yang dimodifikasi pada penelitian ini adalah karbohidrat. Sebelum melakukan uji penelitian , dilakukan terlebih dulu uji penetapan kadar karbohidrat dari Zea mays dan kadar protein dari Arachis hypogea yang dilakukan di Balai Laboratorium Kesehatan Bandung yang bertujuan untuk mengetahui seberapa banyak Zea mays yang ditimbang agar kadar karbohidrat yang ada pada media modifikasi setara dengan kadar karbohidrat yang ada pada media SDA, selain itu bisa dijadikan standar perhitungan untuk berbagai variasi konsentrasi kadar karbohidrat dalam pembuatan media modifikasi. Adapun untuk penetapan kadar protein dalam Arachis hypogea digunakan sebagai pengganti pepton pada media SDA. Kadar karbohidrat dan protein yang didapatkan setelah melakukan uji penetapan kadar yaitu 30,47\% (Zea mays) dan 22,46\% (Arachis hypogea). Berdasarkan kadar Zea mays dan Arachis hypogea yang telah didapatkan, dibuat media modifkasi dengan menggunakan pati campuran bahan tersebut untuk setiap variasi konsentrasi karbohidrat yang berbeda yaitu modifikasi $A$, modifikasi $B$, modifikasi $C$, dan modifikasi $D$.

Saat melakukan uji pendahuluan, yang bertujuan untuk mengetahui pertumbuhan Aspergillus flavus pada media modifikasi Zea mays dan Arachis hypogea, didapatkan hasil pengamatan diameter koloni sama dengan SDA. Pada media SDA area hijau pada koloni jamur lebih tebal dibandingkan media modifikasi. Selain itu juga, dilakukan uji pendahuluan menggunakan kloramfenikol didapatkan hasilnya adalah 0,85 gram dalam $120 \mathrm{~mL}$ yang sesuai agar pertumbuhan jamur Aspergillus flavus tidak terkontaminasi oleh bakteri maupun jamur lain.

Setiap 24 jam selama 5 hari dari hari pertama pertumbuhan jamur diamati secara makroskopis, Aspergillus flavus tumbuh pada hari ke-2 setelah penanaman. Koloni jamur Aspergillus flavus berfilamen, tampak seperti kapas dan beludru, mula-mula koloni berwarna putih kemudian setelah beberapa hari berubah menjadi hijau tua dengan area kuning sulfur pada permukaan koloni, sedangkan pada media modifikasi area permukaan koloni brawarna putih bening,seperti kapas dan koloni jamur berwarna hijau muda. Diukur pula diameter 
koloni menggunakan jangka sorong dengan satuan $\mathrm{cm}$. Pemeriksaan secara mikroskopis dimulai pada hari ke-5 menggunakan mikrometer okuler yang telah dikalibrasi dengan satuan $\mu \mathrm{m}$, Aspergillus flavus tampak di mikroskop memiliki konidiofor yang panjang dan relatif kasar, bentuk kepala konidial bervariasi dari bentuk bola, hifa berseptum, dan koloni kompak.

Adapun kurva pertumbuhan jamur dapat dibagi menjadi empat fase yaitu (Laila dkk, 2006) yaitu : (1) fase lag (fase permulaan) merupakan fase jamur terutama Aspergillus flavus untuk beradaptasi terhadap lingkungannya yang baru. Pada media modifikasi pati Zea mays dan Arachis hypogea maupun SDA Aspergillus flavus mengalami fase adaptasi selama $2 \times 24$ jam pada media tersebut dan memiliki substrat yang cukup; (2) fase logaritma (fase eksponensial) merupakan fase setelah sel mengalami adaptasi dengan lingkungan yang baru sel akan melakukan pembelahan dengan cepat atau mengalami pertumbuhan maksimum karena pada media modifikasi maupun media SDA mengandung nutrisi yang dibutuhkan untuk pertumbuhan jamur Aspergillus flavus; (3) fase stasioner merupakan fase dimana jumlah sel yang bertambah dan mati seimbang karena pada fase ini jumlah nutrisi yang terkandung dalam substrat sudah menipis; (4) fase penurunan disebut juga fase kematian, pada fase ini jumlah jamur akan menurun karena nutrisi yang terkandung dalam substrat mulai menipis.

Selain itu, faktor-faktor yang mempengaruhi pertumbuhan jamur diantaranya : (1) kebutuhan air kebanyakan jamur membutuhkan air minimal lebih rendah dibandingkan khamir dan bakteri; (2) suhu optimum pertumbuhan jamur sekitar $25-30^{\circ} \mathrm{C}$, tetapi beberapa dapat tumbuh pada suhu $35-37^{\circ} \mathrm{C}$ misalnya Aspergillus flavus, (3) kebutuhan oksigen dan $\mathrm{pH}$, jamur dapat tumbuh pada kisaran $\mathrm{pH}$ yang luas yaitu $\mathrm{pH} 2-8,5$ tetapi biasanya pertumbuhannya akan lebih baik pada kondisi asam atau $\mathrm{pH}$ rendah. (4) umumnya jamur dapat menggunakan berbagai komponen makanan dari yang sederhana sampai komplek. Kebanyakan jamur memproduksi enzim hidrolitik misalnya amilase, pektinase, proteinase dan lipase. Oleh karena itu, dapat tumbuh pada makanan yang mengandung pati, protein dan lipid; (5) beberapa jamur mengeluarkan komponen yang dapat menghambat organism lain yang disebut antibiotik, namun untuk pertumbuhan jamur Aspergillus flavus tahan terhadap zat kimia dan antibiotik. Jamur yang memiliki miselium lebih cepat tumbuh dibandingkan dengan jamur yang lainnya (Guinea dkk, 2005; Lan dkk, 2018).

Pertumbuhan jamur Aspergillus flavus pada media modifikasi maupun media SDA sebagai kontrol memiliki perbedaan tetapi tidak terlalu signifikan. Pada media SDA setelah diukur diameternya selama 5 hari, pertumbuhan koloninya sama dengan media modifikasi. Tetapi, pada pertumbuhannya Aspergillus flavus yang ditanam pada media SDA lebih stabil dibandingkan Aspergillus flavus yang ditanam pada media modifikasi Zea mays dan Arachis hypogea.

Secara makroskopis, pertumbuhan Aspergillus flavus pada media modifikasi Zea mays dan Arachis hypogea sama dengan media SDA, tetapi koloni jamur yang tumbuh pada media modifikasi ini belum sama seperti pertumbuhan jamur pada media SDA. Area kuning tua pada permukaan jamur yang terlihat jelas pada media SDA, tidak terlihat begitu jelas pada media modifikasi Zea mays dan Arachis hypogea, selain itu area hijau yang tumbuh pada media modifikasi Zea mays dan Arachis hypogea tidak setebal area hijau yang tumbuh pada media SDA, artinya pertumbuhan jamur Aspergillus flavus pada modifikasi Zea mays dan Arachis hypogea belum optimal. Hal ini dikarenakan kondisi karbohidratsebagai sumber energi, protein sebagai penyusun tubuh, dan mineral sebagai zat yang dapat menunjang 
pertumbuhan spora belum memenuhi syarat untuk pertumbuhanjamur yang optimal (Probst dkk, 2014).

Kondisi ini disebabkan komponen dalam Zea mays dan Arachis hypogea seperti karbohidrat, protein, vitamin dan mineral lebih sedikit dibandingkan dengan kandungan SDA. Pemanasan pada saat pembuatan media juga dapat mempengaruhi penurunan mutu bahan dan perubahan warna, sehingga menyebabkan pertumbuhan jamur tidak optimal. Dengan adanya pemanasan terjadi penurunan kandungan senyawa seperti protein, vitamin, lemak dan senyawa lainnya (Rahma, 2010). Tetapi, secara mikroskopis pertumbuhan Aspergillus flavus pada media modifikasi Zea mays dan Arachis hypogea dengan berbagai variasi konsentrasi karbohidrat yang berbeda sama baiknya dengan Aspergillus flavus yang tumbuh pada media SDA. A..flavus tumbuh menyebar pada setiap media,Penyebaran Aspergillus flavus sangat dimungkinkan karena spora dan konidia yang terbentuk mudah terbawa oleh pergerakan udara atau oleh serangga (Nesci \& Etchevery, 2002).

\section{KESIMPULAN}

Dari hasil penelitian yang telah dilakukan dapat disimpulkan bahwa panjang hifa Aspergillus flavus tidak dipegaruhi oleh perbedaan komposisi media. Dari hasil uji statistik dapat disimpulkan bahwa media modifikasi B (15,75g Zea mays dan 5,34g Arachis hypogea) dapat digunakan sebagai media alternatif pengganti SDA dengan $p$ value 0,188 . Saran untuk penelitian selanjutnya adalah mengobservasi $\mathrm{pH}$ optimum pertumbuhan Aspergillus flavus pada media modifikasi serta uji validasi ketahanan medianya. 


\section{DAFTAR RUJUKAN}

Abrunhosa, L., Paterson, Z.R.R.M., Kozakiewicz, N., Lima, A Venancio. (2001). Mycotoxin production from fungi isolated from grapes. Letters in Applied Microbiology, 32 (4), 240242.

Adisarwanto, T. (2000). Meningkatkan Produksi Kacang Tanah di Lahan Sawah \& Lahan Kering. Penebar Swadaya. Jakarta.

Ernawati, A., Adipati, Y.C. (2017). Identifikasi Jamur Pada Biji Jagung (Zea Mays Busuk dan Segar yang dijual di Pasar Baru Borong Makassar, Prosiding Seminar Biology for Life. ISBN 978-602-72245-2-0.

Cotty P.J \& Jaime-Garcia R. (2007). Influences of Climate on Aflatoxin Producing Fungi and Aflatoxin Contamination. Int J. Food Microbiology, 119 (1-2), 109-115.

Guinea, J. Pelaez, T., Alcala, L., Bouza, E. (2005). Evaluation of Czapeck Agar and Sabouraud Dextrose Agar for the Culture of Airborne Aspergillus conidia, Diagnostic Microbiology and Infectious Disease, 53, 333-334.

Julius P. Sserumaga, Alejandro Ortega-Beltran, John M. Wagacha., Charity K. Mutegi., Ranajit Bandyopadhyay. (2020). Aflatoxin-producing Fungi Associated with Pre-harvest Maize Contamination in Uganda. Internasional Journal of Food Microbiology 313,108376.

Lan, H., Wu, L., Sun, R., Yang. K., Liu, Y., Wu, J., Geng, L., Huang, C., Wang, S. (2018). Investigation of Aspergillus falvus in Animal Virulence, Toxicon, 145, 40-47.

Nesci, A. \& Etchevery, M. (2002). Aspergillus Section Flavi Populations From Field Maize in Argentina, Letter Applied Microbiology, 34, 343-348.

Omeiza, G.K., Kabir, J., Kwaga, J.K.P., Kwanashie, C.N., Mwanza, M., Ngoma, L. (2018). A Risk Assessment Study of the Occurrence and Distribution of Aflatoxigen Aspergillus flavus and Aflatoxin B1 in Diary Cattle feeds in a Central Northern State, Nigeria, Toxicology Reports, 5, 846-856.

Paul W. Kachapulula., Juliet Akello, RanajitBandyopadhyay., Peter J. Cotty. (2017). Aspergillus Section Flavi Community Structure in Zambia Influences Aflatoxin Contamination of Maize and Groundnut. Internasional Journal of Food Microbiology, 261, 49-56.

Probst, C., Bandyopadhyay, Cotty, J.P. (2014). Diversity of Aflatoxin-producing Fungi and Their Impact on Food Safety in sub-saharan Africa, Internasional Journal of Food Microbiology, 174, 113-122.

Reverberi, M., A.A. Fabbri, S., Zjalic, A., Ricelli, F., Punneli, C., Fanelli. (2005). Antioxidants Enzymes Stimulations in Aspergillus Parasiticus by Lentinula Edodes Inhibits Aflatoxin Production, Applied Microbiology Biotechnology, 69 (2), 207-215.

Ruban, V.V., Anbukkarasi, M., Anand, T., Thomas, P.A., Geraldine, P. (2019). Oxidative Stress in Corneal Tissue in Experimental Keratitis duet to Aspergillus flavus : Effect of Topical Voriconazole Therapy, Biocatalysis and Agricultural Biotechnology, 21, 101323.

Samson, R.A., Hoekstra, E.S., Van Oorschot, C.A. (1999). Introducing To Food-Borde Fungi. Centralbureau Voor Schimmelcultures. 